\title{
LATE-VICTORIAN SEXUAL RESPECTABILITY AND THE SOCIAL SYSTEM
}

As others before him, the late Humphrey House once remarked upon the paucity of our knowledge concerning sexual behavior in Victorian England. ${ }^{1}$ For House the extreme reticence of the Victorians magnified the value of every fragment of evidence pertaining to sexual behavior that scholars uncovered. To fathom the meaning of the extreme reticence itself does not seem to have been particularly relevant to the problem for House. ${ }^{2}$ In this paper, which is an analysis of lateVictorian Sexual Respectability, not only the fragmentary sorts of knowledge that House alluded to, but a comparatively unexplored source, medical books, have been made meaningful and interpreted within the frame of reference of the Respectable Social System prevailing in England roughly between 1859 and 1895 .

My conceptualization of the social system assumes the integration in a comprehensive system of relationships of late-Victorian society's (I) stratification system, educational systems, and family structures - all being Respectable relationships or patterns of Respectable relatedness, (2) models of social character and social roles - both integrated into Respectable relationships, (3) morality and normative standards of morality, and deviations - integrated into Respectable relationships, (4) methods of thought - these too were integrated into Respectable relationships, and ( $s$ ) patterns of values, goals, beliefs, attitudes, and ideas - in short, Respectable ideology which was integrated into Respectable relationships. In this paper the analysis is concerned with these categories, but only in so far as they have a bearing on gentlemanly sexual behavior. This paper, then, is devoted to (I) Respectable Sexual Ideology, (II) The Establishment and

1 In the writing of this article I wish to acknowledge my gratitude to the Social Science Institute, Washington University for a summer grant and to the University of Pittsburgh for an Andrew Mellon Postdoctoral Fellowship in history.

2 Humphrey House, All in Due Time (London, 1955), p. $7^{8}$. 
Exposition of the Normative Standard of Gentlemanly Sexual Behavior, (III) The Integration of Continence and Incontinence into the Respectable Social System, (IV) Sexual Respectability and the Logical Method of Thought, (V) Immature love and the Structure of the Respectable family, and (VI) The late-Victorian Revolt.

The endeavor undertaken here to interpret a fragment of mid-and late-Victorian England, its sexual behavior as it pertained to gentlemen, in the larger category of the social system changing as a whole over time is not in itself unique. Many mid- and late-Victorian critics formulated their critiques in terms of the prevailing social system. In "Hard Times" (1854) Dickens attempted to integrate "reason", calculated self-interest, the suppression of feelings, cash-nexus, and social mobility into the social system. Bitzer was the vehicle of this integration. "He had grown into an extremely clear-headed, cautious, prudent young man, who was sure to rise in the world. His mind was so exactly regulated, that he had no affections or passions. All his proceedings were the result of the nicest and coldest calculations and it was not without cause that Mrs. Sparsit habitually observed of him, that he was a young man of the steadiest principle she had ever known." In one passage - the only one in the novel that I can recall where Dickens referred to the social system expressis verbis - he had Bitzer declare: "... I am sure you know that the whole social system is a question of self-interest. What you must always appeal to is a person's self-interest." Moreover, Dickens introduced the circus as a social system and its values in order to mark the contrast with the Respectable Social System and its values. ${ }^{1}$

Dickens was not unique in attaching importance to the social system. Frederic Harrison, the Comtist, assessed the probable meaning of the impending Reform Bill of 1867 in terms of its potential impact upon the established social system. Harrison wrote: "In its influence upon a nation, the set social system will count as ten, whilst any political method will count as one." 2 It is pointed out below (Section III) that Marx conceived his analysis in reference to the social and economic system and that he concluded that the inherent goal in the capitalistic system of production was the compulsion to accumulate and to reinvest capital, or to rephrase Marx' conclusion in the more idealized words of what, according to Robert Lowe, was the function of political economy: to teach "the best way of accumulating the most wealth in the shortest time." 3 Or to take another example. In the

${ }^{1}$ Charles Dickens, Hard Times (Boston, 1895), pp. 152, 380.

${ }^{2}$ Frederic Harrison, Our Venetian Constitution, in: Fortnightly Review, March 1867, pp. 267-68.

${ }^{3}$ Hansard, CC, 4 April, 1870, p. 1200. 
humanist criticism of Matthew Arnold, although he never used the expression social system, he attempted to interpret and to understand the prevailing social system in terms of its relation to English Civilization. For him successive epochs in modern English history were epochs of "concentration' and epochs of "expansion". His own time fell into the latter category, although those clinging to the "social organisation" vigorously resisted "expansion".

"Our present organisation has been an appointed stage in our growth; it has been of good use, and has enabled us to do great things. But the use is at an end, and the stage is over. Ask yourselves if you do not sometimes feel in yourselves a sense, that in spite of the strenuous efforts for good of so many excellent persons amongst us, we begin somehow to flounder and to beat the air; that we seem to be finding ourselves stopped on this line of advance and on that and to be threatened with a sort of standstill. It is that we are trying to live with a social organization of which the day is over. Certainly equality will never of itself alone give us a perfect civilisation. But, with such inequality as ours, a perfect civilization is impossible."

Arnold formulated his criticisms to expose the fetters on expansion which were, according to him, an ascetic morality and religion and the endurance of the aristocracy and its complication of the class structure - all viewed, though not clearly articulated, as integrated in a functioning social system. For Arnold, like Marx, the Respectable Social System frustrated the realization of man's creative potential, his capacity for and his imperative need for expansion, which Arnold found to have become inherent in the development of English Civilization. For Arnold England would become truly civilized as "the whole body of society" came "to live with a life worthy to be called buman, and corresponding to man's true aspirations and powers." In the realization of these dwelled his real happiness. "To have the sense of creative activity is the great happiness and the great proof of being alive." "Man's happiness," Arnold declared in quoting Spinoza, "consists in his being able to preserve his own essence." 1 Or to take one final contemporary example. In 1897 Grant Allen brilliantly analyzed "our existing social system" as structurally frustrating to the

1 Culture and Anarchy (Ist. ed. 1869, London, 1949), pp. 44-45; Mixed Essays (Ist ed., 1879, London, 1903), p. vi, 94-95; Essays in Criticism, first series (Ist ed. 1865, London, I 875), pp. 46-7; and Discourses on America (London, I 885), p. I 21 . For the generation between 1860 and 1890 Arnold's essays are beyond a shadow of a doubt indispensable. 
full realization of individuality and human potentiality. ${ }^{1}$ Actually the social system was a common frame of reference for the late-Victorian critic. There is even a possibility that it may some day be adopted by historians.

\section{RESPECTABLE SEXUAL IDEOLOGY}

While the moral laxity of the double standard of morality represented a significant and prevailing attitude toward gentlemen, it was rivalled and challenged increasingly during the late-Victorian period by Sexual Respectability. According to the strictest expression of Respectability the exclusive purpose of sexual indulgence was the propagation of the species in the holy state of matrimony. Not only was this purpose and limitation sanctioned by the Christian tradition, but it was approved by mid-Victorian representatives of Positivism and Free Thought such as Frederic Harrison and William Lecky. ${ }^{2}$ According to Dr. Acton, a representative of a relatively moderate sort of Sexual Respectability, married sexual indulgence, "taking hardly-worked intellectual men residing in London as a type", "ought not take place more frequently than once in seven or ten days." In instances where "natural desires are strong, I advise those wishing to control their passion to indulge in intercourse twice on the same night." 3 According to Dr. Nichols, a representative of the most extreme sort of Sexual Respectability, married sexual indulgence

1 Grant Allen, Natural Inequality, in: Edward Carpenter (ed.), Forecasts of the Coming Century (London and Manchester, 1897 ).

2 Frederic Harrison, probably the leading exponent of mid- and late-Victorian Positivism affirmed to his son that sexual love was only right in marriage. His son responded, "Positivism, then, takes a theological view about morality?" "Of course... Even more so... A man who gives way to the flesh is a wrongdoer... Morality cannot be twisted about to suit people's tastes." Austin Harrison, Frederic Harrison, Thoughts and Memoirs (London, 1926), pp. I 27-1 29. For W. E. H. Lecky see History of European Morals from Augusta to Charlesmagne (London, I869), II, pp. 371-72.

3 William Acton, The Functions and Disorders of the Reproductive Organs in Youth, in Adult Age, and in Advance Life Considered in Their Physiological, Social, and Psychological Relations (London, I 857), p. 23. "It must, however, be remembered that I am speaking, not of exceptionally strong constitutions, but rather of those that require caution in their management." "Still, as a general rule, the act is and ought to be repeated but rarely." Acton, op. cit. (Philadelphia, 1867), pp. 131, 125 . There are six editions of Acton's book. A second London edition was issued in 1858 , a third in 1862 , a fourth in 1865 , a fifth in 1871 , an a sixth in 1875 . In as much as Acton made revisions and answered his critics I have drawn on various editions and have indicated the edition used each time the work is cited. For the fourth English edition I have had to make use of the Philadelphia edition of 1867 . 
should take place only when the wife was most likely to conceive, and Nichols informed his readers as to the time of the month. ${ }^{1}$ Hence sexual indulgence "for mere pleasure" during the period when conception was unlikely to occur and the use of contraception, natural or artificial, were strongly reprobated. "In the true Christian", remarks a character from Gissing's "The Unclassed", "every enjoyment which comes from the body is sin." 3 Sexual indulgence in excess of the duty to propagate the race was sinful. 4 To reinforce this assertion the strict Respectable mind forewarned of the Nemesis awaiting the children born of unchaste parents. Their children tended to develop premature sensuality. Children born of parents chaste during pregnancy did not tend to develop early amative excitement. ${ }^{5}$

1 T. L. Nichols, Esoteric Anthropology - The Mysteries of Man, (Malvern, 1873), pp. I I4, I 18.

2 Ibid., pp. II4-15. T. L. Nichols, Human Physiology, The Basis of Society and Social Science (London, I872), pp. 3 I $0-1$ I. Nichols condoned contraception only for the sake of the wife's health (Esoteric Anthropology, pp. I13-1 I4). Dr. George R. Drysdale contended that the principal opposition to the mere discussion of the question of contraception was founded upon the fear that discussion in itself would result in "an immense amount of unmarried love." ("A Graduate of Medicine" [G. R. Drysdale], The Elements of Social Science [4th ed., London, I861], p. 348.) Between the first edition of 1854 and 1904 thirty-five English editions of the Elements appeared. The 1887 or 26 th edition was an issue of 65,000. (Norman E. Himes, Medical History of Contraception [Baltimore, 1936], p. 233.) At the time of the Bradlaugh-Besant trial in 1877 , it was widely believed that contraceptive methods would undermine public morality. "It was generally agreed that the 'consequences' of sexual intercourse were the main if not the sole barrier to immoral living on the part of a certain section of the population, and it was feared that the removal of this barrier by the practice of birth control would have a damaging effect." (J. A. and Olive Banks, The Bradlaugh-Besant Trial and the English Newspapers, in: Population Studies, VIII, no. I [July 1954], pp. 27-28.) On the other hand the Bradlaugh-Besant trial marked a turning point in the history of English contraception. Thereafter works containing instruction on contraceptions were far more broadly disseminated and the birth rate declined sharply during the next half century (N. Himes, op. cit., p. 243). Moreover, the upper middle class established a pattern of family limitation - a pattern as Mr. Banks has shown closely associated with the goal of maintaining their standard of living - by late marriage and "prudential restraint". "Continence... is, however, the only natural, and ordinarily, the only justifiable mode of preventing pregnancy." (T. L. Nichols, Human Physiology, p. 310.) The date of change is not exactly clear, but it seems likely that upper middle-class "prudential restraint" was increasingly superseded by contraception during the last thirty years of the nineteenth century. (J. A. Banks, Prosperity and Parenthood [London, 1954], PP. 37, 142, 159.)

3 George Gissing, The Unclassed (London, 1884), I, p. 90.

4 "... ordinary sex-love is only an abuse when it goes beyond what efficient racial continuance requires." M. D. O'Brien, Socialism and Infamy. The Homogenic or Comrade Love Exposed, An Open Letter in Plain Words for a Socialist Prophet, To Edward Carpenter, M.A. (3rd. ed., Dronfield, 1909), p. I3.

5 T. L. Nichols, Human Physiology, p. 273. "I believe that, as in body and mind, so also in the passions, the sins of the father are frequently visited on the heads of the child." Acton, op. cit. (1 862 ed.), p. 6. 
The Respectable aversion for sexual indulgence in excess of its legitimate purpose was theoretically justified by the Respectable theory of sexuality. The psychic sexual sphere being non-existent, sexuality was divided into two distinct spheres: the maternal or paternal instinct and physical desire. The first was an intense and normal instinct and acceptable. Physical desire in women was practically non-existent, ${ }^{1}$ in men strong, but always suspect. Lecky was not alone in thinking that the intensity of the sexual desire was far greater "than the well-being of man requires". 2 The use of contraception was alleged to undermine this natural sexuality. Contraception both aggravated and gratified "physical desire" and at the same time frustrated the parental instinct. ${ }^{3}$

In the strictest sort of Respectability the temptation of sexual indulgence was most frequently presented as a conflict between the highest part of human nature, referred to either as the soul or "reason", and the lowest part of human nature, the body or "appetite". "Mankind are moved," wrote M. D. O'Brien, "by appeals to the two elements into which human nature may be finally resolved, namely reason and appetite." "Reason is man's strength, appetite his weakness." "The strongest hold which animalism has over the race lies in the sexual passion", wrote Archbishop Ireland. "The triumph over this passion, the reduction of it under the law of reason, is the supreme act of Spiritual power in man." ${ }^{5}$ Agreement as to the eternal conflict between appetite or instinct and reason was practically unanimous until the eighties and nineties. ${ }^{6}$ Not only the Evangelicals, ${ }^{7}$ also rationalists like Lecky $^{8}$ and even anti-vivisectionists ${ }^{9}$ and phrenologists detected a sharp schism between body and soul. The so-called animal faculties

${ }_{1}$ See Section III (in the next issue of this journal).

2 Lecky, op. cit., II, p. 298. “... in the present state of society all tends to prove it is restraint, not excitement, which we seem to require." The excitement referred to was induced by the prepuce which, according to Acton, aggravated "an instinct rather than supplied a want." Acton, op. cit. (I 862 ed.), p. 24.

3 M. D. O'Brien, The Natural Right to Freedom(London, 1893), p. 220.

4 M. D. O'Brien, Socialism and Infamy, p. I6.

5 Archbishop Ireland, Social Purity, in: Humanitarian, 1 894, p. 269.

- The exceptions were noted late-Victorian rebels such as Havelock Ellis, Grant Allen, Edward Carpenter, and John Addington Symonds.

7 Ken Inglis, English Nonconformity and Social Reform, 1880-I 900, in: Past and Present, April I958, p. 83 .

8 "... the sensual side of our being is the lower side, and some degree of shame may be attached to it." Lecky, op. cit., II, p. 294. “... we have an innate, intuitive, instinctive perception that there is something degrading in the sensual part of our nature ..." Ibid. pp. 107-08.

- Sundry Members, Clerical, Medical, and Lay of the International Association for the Total Suppression of Vivisection, "The Woman" and the Age: A Letter Addressed to the Right Honourable W. E. Gladstone, M.P. (London, 1881). 
were said to be located at the back of the head and in the inferior part of the brain. The so-called moral and religious faculties were thought to be located upon the top or superior part of the brain. ${ }^{1}$

In the strictest sort of Respectability the radical opposition between body and soul obscured the distinction between sensuousness and sensuality, between the fact of human nature and lust. M. D. O'Brien expressed the confusion when he wrote that sexual love was always sensual. In true love there was no passion. "It is light without fire; it is god-like, grand and pure." "... All passion is immoral; a perfect life would not have a trace of it." " Sexual indulgence had "absolutely nothing to do with love. There undoubtedly is such a thing as desire, but there is no such thing as sexual love." Sexual desire provided the motive force for the propagation of the race. That duty performed, sexual desire still craving satisfaction provided the motive force for sensuality. Ideal love, for O'Brien, was the province of religion. The few who knew and loved God were the few who really knew love; the many were "in bondage to lusts of one kind or another". ${ }^{3}$ The man who became a priest commented the Respectable Clement Scott, conquered "that worst of all foes from boyhood to old age, the enemy, Nature." 4 In the strictest sort of Respectability ideal love was a kind of absolute religious sublimation. The propagation of the race itself became a sort of ascetic compromise. Sexual love at its best was a mark of human frailty; at its worse, a damnation.

Against the strictest sort of Respectability was opposed a more moderate sort represented by Dr. Acton. For him the radical opposition between reason and appetite applied only to unmarried gentlemen who must be "absolutely continent", not to the married gentleman who must be "moderate" in sexual indulgence. "Not that this natural instinct is to be regarded with a Manichean philosophy, as in itself bad. Far from it. That it is natural forbids such a theory. It has its beneficient purpose; but that purpose is not early and sensual indulgence, but mature and lawful love." Acton, earnestly concerned with what he regarded as a prevailing sensuality, opposed married indulgence for pleasure in itself separated from the ends intended by "the order of nature" and God. Indulgence, wrote Acton in quoting Jeremy Taylor, a seventeenth century bishop, "should never be

1 Professor James Barker, A Secret Book for Men Containing Personal and Confidential Light, Instruction, Information, Counsel and Advice for the Physical, Mental, Moral, and Spiritual Want of Boys, Youths, and Men; being an Expose of the Vice of Boyhood, the Blight of Youth, the Curse of Men, the Wreck of Manhood, and the Bane of Posterity (Brighton, I89I), p. 26.

2 M. D. O'Brien, The Natural Right to Freedom, pp. 260-6x, 257).

3 M. D. O'Brien, Socialism and Infamy, p. 25.

4 "An Equal Standard of Morality." Humanitarian, Nov. 1894, p. 354. 
separate from those ends, but always be joined with all or one of these ends, with a desire of children, to avoid fornication, or to enligbten and ease the cares and sadness of bousebold affairs, or to endear each other; but never with a purpose, either in act or desire, to separate the sensuality from these ends which hallow it." 1 Charles Kingsley and Coventry Potmore, too, assumed a moderately Respectable position in respect to married love in their endeavor to lift the aura of suspicion that enveloped sexual love and to make it acceptable. ${ }^{2}$

Feelings of "pleasure" being a concomitant of manifestations of the sexual "appetite" or instinct, the antagonism between "appetite" and "reason" was either broadened or transmuted into a conflict between reason and sexual feeling. The emotions associated with sexual love were found guilty by association. Moreover, the guilt spilt over to make emotions generally somewhat suspect. Reason and feeling were diametrically opposed (unless the feelings were "spiritualized" meaning devoid of any apparent sexual association), and considered of a higher and lower order. "We may surely affirm with confidence", wrote Professor Mivart, "that if there is one distinctive characteristic whereby human nature is elevated above that of the brutes, its is our power of recognizing that we have feelings and desires, that they are altogether inferior to our intellectual perceptions, and that our actions should accord with right reason at whatever cost to feeling." 3 While "Hard Times" (1854) expressed the conflict in art, ${ }^{4}$ John Stuart Mill provides an excellent case study from Victorian reality. "Compared with the domain of ideas, abstractions, and universal laws in which Mill tried to live with his strong father, everything psychologically represented by a boy's mother seemed petty and futile, in his own nature as well as in others. Personal feelings, attachments, physical sensations, pleasures, and pains seemed to him like so many nonsensical and mostly inconvenient, or embarrasing trifles." This aversion from all feeling debarred Mill from every intimate emotional contact. He was frightened of personal emotions involving him with others. "My father's older children", Mill wrote, "neither loved him nor with any warmth of affection anyone else... I had no one to

1 Functions (1867 ed.), pp. 45, 131, 75, 77 Acton's italics.

2 Walter E. Houghton, The Victorian Frame of Mind, I830-1 870 (New Haven and London, 1957), pp. 39r, 375-76.

3 "The Degradation of Women," Humanitarian, Oct. I896, p. 256.

4 In Gradgrind's words, "I have systematically devoted myself (as you know) to the education of the reason of my family. The reason is (as you know) the only faculty to which education should be addressed." C. Dickens, Hard Times, pp. 23-4. "You have been so well trained... You are not impulsive, you are not romantic, you are accustomed to view everything from the strong dispassionate ground of reason and calculation." Ibid., p. 127. 
whom I desired to express everything which I felt..." Mill was reluctant to give affection. "In him Logos was forever engaged in slaying eros." 1

In this respect it is worthwhile noting that Dr. Thomas Arnold, the famous public school reformer, had misgivings about the public school system in as much as it entailed "the alienation of the boys from home influence." "You sometimes," Dr Arnold said, "learn to feel ashamed of indulging your natural affections, particularly of being attached to your mothers and sisters, and fond of their society. ... I am afraid, it cannot be doubted, that it is peculiarly the effect of the public schools of England to lower and weaken the connexion between parent and child, to lessen mutual confidence, and to make a son regard his father with more of respect than of love. Certainly, at least, the relation in other countries of Europe is on a different footing; there is more of cordial intimacy, more of real familiar friendship between parents and children than generally exists among us." 2 Boys learned to stifle their desire for kindness and mothering which they retained from childhood, because these were thought to constitute an "unmanly" influence. Similarly, Edward Carpenter drew attention to the emotional immaturity of the public-school educated gentleman - "in the most important matters quite ungrown". "Affection and tenderness of feeling, though latent in him, have never, owing to the unfortunate condition of his life been developed; but their place begins to be taken by a rather dreary cynicism." ${ }^{3}$ Carpenter contrasted this type of public school gentleman with the working man

${ }_{1}$ Ruth Borchard, John Stuart Mill, The Man (London, 1957), pp. 33-5. Mill's own theory of education was an attempt to rectify the deficiency of the one he had received. "The education of the feelings, and the cultivation of the beautiful," Mill wrote, was "needful to the completeness of the human being." (J. S. Mill, Inaugural Address (London, I 867), p. 86.) In their attitudes towards reason and emotion there is a striking resemblance between Freud as a late-Victorian and Mill. Like Mill, Freud too exalted reason in opposition to the emotions. "He made love an object of science, but in his life it remained dry and sterile. His scientific-intellectual interests were stronger than his eros; they smothered it, and at the same time became a substitute for his experience of love." To Freud, "the aim of life for a civilized person was to suppress his emotional and sexual impulses, and at the expense of this suppression, to lead a civilized life. It is the uncivilized mob which is not capable of such sacrifice. The intellectual elite are those who in contrast to the mob were capable of not satisfying their impulses, and thus sublimating them for higher purposes. Civilization as a whole is the result of such nonsatisfaction of instinctual impulses." (Eric Fromm, Sigmund Freud's Mission. Cf. below, p. 35, fn. 2. An Analysis of his Personality and Influence (New York, 1959), pp. 28, 33-4). For the same opposition between reason and feeling in Darwin, see the brilliant essay by Donald Fleming, "Charles Darwin, The Anaesthetic Man," Victorian Studies, IV (March 196r).

2 Sir Joshua Fitch, Thomas and Matthew Arnold and their Influence on English Education (New York, 1899), pp. 88-9.

3 Edward Carpenter, Love's Coming of Age (London and Manchester, 1903), pp. 29-30. 
who "has been called upon in a thousand ways to help his parents, or his brother and sisters, and has developed a fair capacity of sympathy and affection - a thing which can hardly be said of a public school boy ..." 1

While in this section Respectable sexual ideology has been systematically presented, it is a purpose of this paper to show that much of this conscious Respectable thought about sex was nothing more nor less than what Marx called a "false" consciousness, an ideology and rationalization of Respectable sexual actions. Their real mainsprings about which Respectable late-Victorian gentlemen were unconscious and therefore self-deceived were the Respectable Social System and the social character of the Respectable "Christian gentleman" integrated into that system. These determined Respectable Sexual Ideology.

\title{
II
}

\author{
THE NORMATIVE STANDARD
}

OF GENTLEMANLY SEXUAL BEHAVIOR

Respectable sexual attitudes and motives passed into Respectable thought about the normative standard of gentlemanly sexual behavior. In Respectable thought, as we shall see, sexual motives were abstracted from human nature (constructed into a model) for analysis in a manner analogous - though not nearly so consciously - to the procedure carried on in the study of classical political economy. ${ }^{2}$ Thus, a brief consideration of the methodology of classical political economy ${ }^{3}$ is

1 Ibid., p. 32.

2 "... we must translate the other phenomena of human and social history into terms of functional and structural analysis. It is high time that everything which the classical economists have done for economic behaviour should also be done for social behaviour." Karl Mannheim, Man and Society in an Age of Reconstruction, trans. by Edward Shils (New York, I940), p. 26.

${ }^{3}$ On the methodology of classical political economy, see J. S. Mill, "On the Definition of Political Economy; and on the Method of Investigation". This essay was drafted during the years of Ricardian triumphant between I 829 and I 833 . (See W. J. Ashley, The Present Position of Political Economy (London, 1907), p. 5). Mill's essay was first published in the London and Westminister Review, Oct. 1836 . It was published again in Essays on Some Unsettled Questions of Political Economy (London, I844). A second edition was issued in 1874 . The definitive mid-Victorian treatise on methodology was J. E. Cairnes, The Character and Logical Method of Political Economy (London and Dublin, 1857). A second edition was issued in 1875. See also Professor Henry Fawcett's "Inaugural Lecture on Political Economy," Macmillans' Magazine, April 1864. J. N. Keynes' 'The Scope and Method of Political Economy (London and New York, 189x) superseded Cairnes' exposition. 
useful for understanding Respectable sexual thought and the norm of sexual morality.

In their analysis of economic behavior the classical economists proceeded by abstracting from human nature exclusively economic motives. Their abstraction constituted the model of their economic thought, Homo Economicus. The model was endowed with certain opposing economic motives. On the one hand the economic man desired wealth. In the prevailing Respectable Social System the desire for wealth signified two sorts of economic motives that may be summed up as a desire for the status of comfort and a desire for the comfort of status. First, the desire for wealth signified a desire for the means to maintain a high standard of comfortable living, an incentive clearly determining the postponement of marriage among gentlemen.

"As a general rule, a man does not marry in the middle and upper classes, unless he believes that he shall at any rate be able to give his children as good an education as he has himself received, and be also able to place them in a social position, similar to that which he himself occupies. The majority of men are accustomed to some particular style of living; and they generally refrain from marriage, if the increased expenses of married life would compel them to live in a manner which would not give them what has been aptly termed 'their habitual standard of comfort'. ... A person in the middle class appreciates the value of the position he occupies; and he will not marry, if marriage will so impoverish him as to render it necessary for him to resign his social position."1

Second, the desire for wealth signified a desire for the means to achieve a higher social position. "In modern life the individual wishes, not to stand well in his class, but to rise out of his class to a better social grade; and since wealth gives the means of gratifying that ambition, the desire of wealth has become a dominate factor in the minds of most men." 2 Opposing this positive motive were two negative mo-

1 Henry Fawcett, The Economic Position of the British Labourer (Cambridge and London, I 865 ), pp. 43-45. The Saturday Review referred to the existence "in the minds of the comfortable classes of a standard of comfort which discourages early marriages." I 860 , p. 107 .

2 William Cunningham, "The Comtist Criticism of Economic Science," Report of the British Association, 1889 , p. 466 . For a really brilliant essay charging the classical economists with oversimplifying the desire for wealth and with neglecting its changing meaning over time and in different civilizations, see T. E. Cliffe Leslie, "On the Philosophical Method of Political Economy," Hermathena, Vol. II (1876), pp. 265-97, and his "The Love of Money," Exchange, Nov. I862. Leslie's essays were reprinted in his Essays in Political and Moral Philosophy (Dublin, 1879). “The desire of wealth is a general name for a great variety of wants, desires, and sentiments, widely differing in their economic 
tives: the aversion for labor and the desire for the present enjoyment of costly indulgences. The model was allegedly neutral in the sense that the economists believed that it was free of value judgment and represented economic motives as they actually influenced the individual's economic behavior in the prevailing economic system. The individual could resolve the conflict of economic motives in at least two significant ways.

The first resolution constituted the norm of Respectable economic behavior. The Respectable man resolved the conflict virtuously through this strength of character. He overcame his aversion for labor by imbibing the economic virtue of industry. He overcame his desire for costly indulgences by adopting the virtues of thrift, prudence, sobriety, and continence. "... we assume that our economic man is a respectable married man who wished to provide for his family, ${ }^{1}$ and calculate out what he will do on this supposition ... We then formulate the "laws" for what such people will tend to do, and point out ... that they are $\ldots .^{2}$ honest sort of well-to-do folk, with no heroic virtue and much prudent regard for the future." ${ }^{3}$ In this resolution of the conflict of economic motives the desire for wealth largely determined the economic behavior of the classes who possessed "their habitual standard of comfort" or had a higher social position within their grasp.

A second resolution of the conflict of economic motives constituted the most extreme deviation from the Respectable norm. Unlike the first resolution the incentive of wealth did not determine economic behavior for the classes who possessed neither the comfort (the "very poor ... are not restrained from marriage by a desire to preserve a certain standard of comfort"4), nor the hope or prospect of attaining it in spite of the efforts of mid-Victorian radicals, like Professor Fawcett, who dedicated themselves to making the very poor Respectable. But England had not yet arrived at the total victory of what Mill called the "mediocrity of respectability which is becoming a marked characteristic of modern times," 5 or at the condition of its victory, affluency, and so where wages were inordinately low the incentive for

character and effect, undergoing fundamental changes in some respects, while preserving an historical continuity in others ... So all the needs, appetites, passions, tastes, aims and ideas which the various things comprehended in the word wealth satisfy, are lumped together in political economy as a principle of human nature which is the source of industry and the moving principle of the economic world." Hermathena, pp. 269-70.

1 Alfred Marshall, The Economics of Industry, p. vi.

2 Alfred Marshall, Principles of Political Economy, p. 293.

3 William Cunningham, "A Plea for Pure Theory," Economic Review, II (Jan. I 892), p. 40.

4 Henry Fawcett, op. cit. p. 44.

5 J. S. Mill, The Subjection of Women (London, 1869), p. 169. 
the poor to labor was provided by the New Poor Law, not their conversion to Economic Respectability. Of three choices: work, starvation, or the work house, the first was calculated to give the least offense. When it did not, the deviation from the norm of Respectable and regular economic behavior characterized the economic behavior of the lowest strata of the class structure, the so-called Residuum.

"The ideal economic man, as we know, is remarkable for his foresight and self-control; in the Residuum these qualities are entirely absent. In place of foresight we find the happy faith which never fails, that "something will turn up", instead of selfcontrol the impulsive recklessness which may lead indifferently to a prodigal generosity, or an inconceivable selfishness. The true type of this class lives in the present moment only; not only is he without foresight, he is almost without memory, in the sense that his past is so completely past that he has no more organized experience to refer to than a child. Hence his life is one incoherent jumble from beginning to end... there is no development in it; all is aimless and drifting."

Similar observations to those made in respect to the abstraction of the economic man, can be made in respect to the abstraction of the sensual man, Homo Sensualis. Although more than one model is discernible in Respectable thought, they are all for the most part models for the unmarried gentleman. All models were endowed with certain sexual motives, conceived as being absolutely irreconciliable and characteristic of human nature. In the worldly model implicit in the thought of Dr. Acton and Dr. Mercier, the positive secular motive, the desire for success, was irreconciliably opposed by negative motives: (I) by the aversion for labor, the means for earning success through sublimation, and (2) by a desire for the immediate gratification of the sexual appetite. In the more religious model implicit in the thought of F. W. Newman and Dr. Nichols the positive religious motive, the desire for purity or continence (being the will of God) was opposed by the same negative motives that formed Dr. Acton's model. Actually neither model was formed by purely secular or purely religious motives. In Acton's listing of "aids to continence" religion came first. He provided his reader with two full pages of religious titles on the subject. His own frequent complaint was that the Churches were too timid and reticent on the subject of continence and "the consequences of unrestrained licentiousness". The Church of England

1 H. Dendy, "The Industrial Residuum," Aspects of the Social Problem, ed. Bernard Bosanquet (London and New York, I 895), p. 83. 
did "not deem it expedient to be very diffuse upon the observance of the Seventh Commandment." The writings of Dissenting ministers contained "very few discussions of the subject of sexual temptations" which could "be appealed to as real aids to continence." Reluctantly Acton assumed the role of religious adviser because of the frequent letters he received from young men "seeking advise how to curb the lust of the flesh." As a proselytiser of continence Acton wanted his profession to perform a function in which the Churches were delinquent ("no one can so well interfere as the medical man") in order to arrest "the easy descent" of the incontinent "from comparative happiness and respectability". In each model under consideration appeals were made to both secular and religious motives. The models differed only in the relative weight of the appeal to these diverse motives. In fact the fundamental differences between the two models was the goal being pursued. In the first case it was success, in the second purity. In the first case, although sensuality concerned Acton as a problem in itself, purity was advocated as a means to success. In the second case, purity, the triumphant over sinful indulgence, was both the means and the end in itself. Beyond this difference of goals the models were the same.

The individual could resolve the conflict of irreconciliably opposed sexual motives in at least two significant ways. The first resolution constituted the norm of Respectably sexual behavior. If the desire for purity or success, developed by conscience or "duty", conquered or thoroughly sublimated the sexual "appetite" through sustained work, the sensual man became virtuous or perfectly continent. In short, the perfectly continent, the completely sublimated sensual man, represented the Respectable or normative standard of gentlemanly sexual morality. Perhaps, the ultimate ideal of Respectable sublimation was rescue work among fallen women, the chief instrument of incontinence. Such a preoccupation was a life-time engagement for W. E. Gladstone. In the words of his biographer, "He had schooled himself early in life to sublimate the tensions which seethed inside him. His rescue work was an important aspect of that process of sublimation." 2

1 Acton, op. cit. (1867 ed.), pp. 55-61, 27I. In her campaign against the Contagious Diseases Acts which were a legalization of the double standard of morality, Josephine Butler found the Church of England for the most part hostile or indifferent. In I 871 a gathering of clergymen howled down Cannon Butler for attempting to read a paper on the double standard. Quakers and Nonconformist ministers sided with Mrs. Butler and denounced the Government. (See E. M. Turner, Josephine Butler: An Appreciation (London, 1927) pp, I I-2). While the "classes" were hostile to Mrs. Butler's campaign, the North country working classes were sympathetic. (See Virginia N. Crawford, Josephine Butler, Croydon, 1928, pp. 3-5, and Josephine E. Butler, Social Purity, London, 1879, p. 22).

2 Philip Magnus, Gladstone, A Biography (London, 1954), p. 107. 
For those less high-minded continence was not only a norm of the waking hours, but according to the most extreme sort of Sexual Respectability gentlemen were to be continent even in their dreams. Manifestations of the sexual instinct being so generally suspected, nocturnal emissions aroused deep feelings of guilt. "Men of scrupulous conscience," wrote Sir James Paget, "are deeply distressed with the thought that the emissions are due to sexual feelings which they might be able to suppress even in their dreams; they look on them as tokens of a prevalent impurity of mind which they must cure." ${ }^{1}$ Doctors, like T. L. Nichols, probably exacerbated those feelings of guilt by unconditionally declaring seminal emissions to be a manifestation of disease; and in nine cases out of ten, he said, they were a result of masturbation. "Hundreds of young men are driven to suicide by this disease," Nichols wrote. ${ }^{2}$ Many others were unmercifully exploited by quacks. ${ }^{3}$ Paget, being more sensible than Nichols, advised medical students to allay their patients' anxiety by telling them that their emissions were natural in those who were chaste. Emissions were irrepressible, and evidence of a healthy nervous system. ${ }^{4} \mathrm{~A}$ frequently published pamphlet took the same line. ${ }^{5}$ In the 1862 edition of his book Acton had declared nocturnal emissions to be not only compatible with but a consequence of continence. Conceding that emissions occurring rarely might not be a great source of mischief, Nichols, unlike others, did not consider them a natural mode of relief. ${ }^{6} \mathrm{He}$ believed that the "will" could be so strengthened by motives of conscience and religion that "actions which seem to be involuntary" could be conquered. "A man who has a vivid sense of right and duty of refraining from sensuality," sermonised Nichols, "and preserving his own purity of mind and body, and chastity of all women, will do so even in his dreams."' Similarly, having revised his earlier opinion, Acton was confident in the individual's "power of keeping his dream thoughts pure" and in "his duty and his true profit to endeavour to do so". "Patients will tell you that they cannot control their dreams. This is not true." Dr. Acton evidenced a letter in which was stated "the possibility of schooling the will so as to awake in time to prevent emission." The troubled correspondent wrote: "I have learned so to

1 Sir James Paget, Clinical Lectures and Essays (2nd. ed., London, I 879), p. 292.

2 T. L. Nichols, Anthropology, Pp. 295-98.

3 "A Graduate", A Lecture to Young Men on the Preservation of Health and Personal Purity of Life (sth ed., London, I889), pp. I3-16.

4 Sir James Paget, Essays, pp. 292-93.

5 "A Graduate", (7th ed., I892).

6 T. L. Nichols, Anthropology, p. 296.

7 T. L. Nichols, Psychology, pp. 304-05.

8 Functions (1867 ed.), p. I95. 
school my mind during sleep, that I awake in time to prevent a catastrophe." 1 Acton concurred that it was dangerous to prevent ejaculations mechanically by pressure in the perinaeum, or by tying a cord around the penis.

A second resolution of the conflict of sexual motives constituted the deviation from the Respectable norm. If the sexual "appetite" conquered the desire for purity or success, the sensual man became vicious or incontinent. The deviation characterized the sexual behavior of the lower classes particularly, though not exclusively, as some gentlemen were deviants. In industrial and mining districts, where child labor substantially enhanced the family income, the lower classes considered it unthrifty and unnecessary to marry a woman who had not given evidence of fertility. The attitude was expressed in a North country proverb. "If thou houd'st, I wed thee; if thou doesn't, thou'st none the waur." 2 In particular the most marked deviation from the Respectable norm characterized the Residuum. "Decency and cleanliness," wrote Thomas Wright who knew well the overcrowded living conditions of the lower classes, "cannot be maintained among the respectable poor; among the reckless poor there is no attempt to maintain them." Promiscuity and immorality were openly indulged. ${ }^{3}$ Overcrowded slums and drink generally were adduced to explain lower-class deviations from the Respectable norm. The picture is in fact more complex and is beyond the scope of this essay. Here the point of emphasis is the "immorality" of the poor so thoroughly documented in Royal commission reports and in the studies of Henry Mayhew, Havelock Ellis, and Charles Booth, "The overcrowded houses of the poor compel the children to witness everything," wrote General William Booth in I 890. "Sexual morality often comes to have no meaning to them. Incest is so familiar as hardly to call for remark." "I understand that the Society for the Protection of children prosecuted last year a fabulous number of fathers for unnatural sins with their children. If so many were brought to justice," Booth enquired, "how many were there of whom the world never heard in any shape or form?" 4 If the Residuum were the acknowledged antithesis of the Respectable economic man in his economic behavior, so were they the antithesis of the Respectable sensual man in their sexual behavior. At the lowest social level where there was

1 Ibid., p. 201.

2 W. Acton, Prostitution, Considered in its Moral, Social, and Sanitary Aspects, in London, and other Large Cities and Garrison Towns, with Proposals for the Control and Prevention of its Attendant Evils (2nd ed., London, I 870), p. 47.

3 Our New Masters (London, I873), pp. 49-5I.

4 In Darkest England and the Way Out (New York and London, I89o), pp. 65, 193. 
much brutalization, there was also much sensuality without affection, while at the highest level, as we shall see (Section III), there was much affection without sensuality.

The model of the economic man and of the sensual man were differentiated by two contrasting assumptions. The economic man, when guided by his own self-interest, was assumed to know his own economic interests. The sensual man, when guided by "nature", 1 was assumed not to know best his own sexual interests. Knowing best his own economic interests, being knowledgeable about market conditions, and doing best for himself, the economic man did best for everyone else as well. Not knowing best his own sensuous interests, being inclined to sexual indulgence or sin, the sensual man was exhorted to conform to what was declared to be his best interests, the established Respectable norm. Its maintenance depended upon ignorance. And although Acton's book is an impassioned plea against reticence and for the making available to young men medical knowledge relating to the evils of incontinence, his book for the most part was a catalogue of Respectable attitudes and an exposition and defense of the Respectable norm. What Acton as a Respectable moralist called for was not a disinterested enquiry into the psychology of sex, but a broadcasting of the evils following upon deviation from the norm. Notwithstanding Acton's effort, sexual reticence and ignorance was the uncompromising order of late-Victorian England. No subject was so carefully shrouded under a veil of secrecy and tabooed from disinterested enquiry. ${ }^{2}$ The prevailing prejudice had it that civilized decency required strict reticence. "Ignorance about sexual affairs

1 “' Nature! Don't talk of so vile a thing as nature,' said my mother. 'It's following nature that leads men to perdition,' and she looked at me as she spoke.” B. Aiken (ed.), Waiting for the Verdict, an Autobiography (London, I863), p. 64. In the novel the mother is a conscientious and strict Calvinist. Ibid., pp. 18, 26-28, 37, 61.

2 When England was seething in Revolt (see Section VI below), sexual reticence was forcefully challenged, its best single expression, among many, being the work of Havelock Ellis commenced in the eighties. The challenge extended to the novel hitherto shrouded behind a number of protective barriers which compelled novelists to be reticent. When, however, in the mid nineties a new school of fiction dared to be sensuous, to be forthright about the sexual side of life, it was violently attacked as repulsive and neurotic. "Its morbid spirit of analysis", its characters "being so dreadfully introspective", "their maddening faculty of dissecting and probing their "primary impulses" - especially the sexual ones," their explorations into the innermost recesses of they human heart, provoked the wrath of many Respectable-minded critics (Hugh E. M. Stutfield, "Tommyrotics", Blackwood's Magazine, June I895, p. 490). The new fiction, they said, smacked of "sexual sensualism." (J. A. Noble, "The Fiction of Sexuality," Contemporary Review, April I 895, p. 490). The new novels were stigmatized "the sex maniacal novels" ("The Philistine", The New Fiction and other Papers (London, 1895), p. 85). 
seems to be a notable characteristic of the more civilized part of the human race." 1 The most significant ignorance was the assumption that control of sexual passion was strictly a physical matter (the psychic sexual sphere being non-existent) dependent upon strengthening the will, not a psychological problem. "It is a solemn truth," wrote Acton, "that the sovereignty of the will ... is a matter of babit. Every victory strengthens the victor. With one, long years of courageous self rule have made it apparently impossible for him ever to yield. The whole force of his character, braced and multiplied by the exercise of a lifetime, drives him with unwavering energy along his choosen course of purity ... With another, the first concession, the first lost battle between the will and a temptation, is but the commencement of a long series of failures. Every succeeding conflict is harder because the last has been lost." 3 And not only was the wielding of a strong will possible, but the inability to do so was held to be a grave moral delinquency. "...the sentiments and passions of man have been generally considered subservient to the will and reason, and ... any undue excitement of the former has been consequently supposed to arise either from a criminal want of control on the part of the will, or from a deficiency of rational power; so that, according to this view, a man of violent passions or eccentric conduct, unless proved to entertain some delusion or hallucination, must be either wilfully perverse or chargeable with moral delinquency." 4 To hold this intel-

1 Sir James Paget, op. cit., p. 292.

2 "The essence of all this training of the will, however, lies in beginning early." Acton, op. cit. (1 862 ed.), pp. 42-45; (1857 ed.), p. 6. "A man can only achieve strength of purpose by the action of his own freewill... he can shun sensualism, and be continent". (Samuel Smiles, Character (Chicago, New York, and San Francisco, I889), p. 214). In contrast to the Respectable assumption that a strongly developed will could achieve the conquest of passion by reason, Freud opened up new vistas. Freud, too, wanted mankind to achieve "the conquest of passion by reason." "Up to Freud the attempt had been made to dominate man's irrational effects by reason, without knowing them, or rather without knowing their deeper sources. Freud, believing that he had discovered the scources in the libidinous strivings and their complicated mechanisms of repression, sublimation, symptom formation, etc., had to believe that now, for the first time, the age-old dream of man's self-control and rationality could be realized". (Eric Fromm, op. cit., pp. 93-4). "The making conscious of repressed sexual desires in analysis makes it possible, on the contrary, to obtain a mastery over them which the previous repression had been unable to achieve." Sigmund Freud, General Introduction to Psychoanalysis, chapter 27.

3 Acton, op. cit. (1867 ed.), p. 60 . The character of Gladstone is an excellent exemplification of an iron-will. See P. Magnus, op. cit., pp. 38, 104-5, 382.

4 Hack Tuke, Prichard and Symonds in Especial Relation to Mental Science with Chapters on Moral Science (London, 1891), p. 49. Although opposed to the belief, Dr. Tuke made the statement in his exposition of "moral insanity", a conception introduced by Dr. Prichard in 1835 . Derangement of the "moral faculty", according to Prichard, constituted moral insanity. Both Prichard and Dr. Symonds were sympathetic to the hitherto 
lectual position was to erect a most potent barrier to understanding and to secure the ignorance of the psychology of sex. And ignorance was indispensable to the maintenance of the irreconciliable opposition between the sexual motives that constituted the abstraction of the sensual man. For while the irreconciliability of motives made the Respectable norm rigid and unchanging by prohibiting and arresting its development, the taboo on enquiry itself worked against the discovery of the sort of knowledge (e.g. that the nature of lateVictorian sexual repression not only often distorted an irrepressible instinct, ${ }^{1}$ but arrested the development of a mature character) that endangered the security of the Respectable norm. Otherwise stated, ignorance was a defence mechanism of the Respectable norm. The less known, the greater the taboo on enquiry, the more entrenched, the more secure, the more impervious of criticism the Respectable norm.

Although gentlemen, too, deviated from the Respectable norm, for them sublimation and continence, like work, were made Late Victorian gospels. The medical profession, the Public School System, "Good Society", and writers expended much energy in the establishment, exposition, and defense of the Respectable Norm. Dr. William Acton in the 1857 edition of his book urged the exhaustion of physical and mental energies in boyhood and adolescence so that "in accordance with natural laws the expenditure of vital force in one direction diverts it from others." 2 In the $186_{2}$ edition of his book Acton reduced the theory of sublimation to an exact formula. "I have already alluded to the fact that the intellectual qualities are usually in an inverse ratio to the sexual appetites. It would almost seem as if the two were incompatible; the exercise of the one annihilating the other." For the continent Acton held out the hope of distinction. For the incontinent he prophesized wasted energy and relative oblivion. "All experience tends to prove," wrote Acton, "that if a man observes

unacknowledged "morally insane" who suffered "marked obliquities which are so easily confounded with bad passions willfully indulged and evil habits pursued." (Ibid., p. 50). "... it must be remembered that a theory of insanity apart from mental delusions was at that time [1835] novel, almost revolutionary." (Ibid., p. $5 x$ ). The "echoes" of the controversy provoked by the theory had not died away at the time of Tuke's writing in I89I.

1 "In this particular field the evil of ignorance is magnified by our efforts to suppress that which never can be suppressed, though in the effort of suppression it may become perverted." Havelock Ellis, Studies in the Psychology of Sex (Philadelphia, I925) I, I897 Preface, p. iii.

2 Functions ( 1857 ed.), p. 8. "The vital force must act in some direction; and if we would not have it expended on dementiveness and amativeness, we must direct it to other and nobler uses." T. L. Nichols, Esoteric Anthropology, p. I 20. 
strict continence in thought as well as deed, and is gifted with ordinary intelligence, he is more likely to distinguish himself in liberal pursuits than those who live incontinently, whether in the way of fornication or by committing marital excesses." 1 The fourth edition of Acton's book contained the confirmation of experience as to what a resolute will could achieve. A correspondent related how he maintained a perfectly continent pre-marital life. "During my university career my passions were very strong, sometimes almost uncontrollable, but I have the satisfaction of thinking that I mastered them; it was however, by great effort. I obliged myself to take violent physical exertion; I was the best oar of my year and when I felt particurly strong sexual desire, I sallied out to take more exercise. I was victorious always; and I never committed fornication; you see in what robust health I am; it was exercise that alone saved me." Acton then triumphantly announced that his correspondent had taken "a most excellent degree" and had reached the pinnacle of his profession. "Here is an instance of what energy of character, indomitable perseverance, and good health will effect." Not only were exercise and diet necessary "aids to continence" bringing the body into subjection, but so were religion, training of the will, and healthy and intellectual employment and amusement. ${ }^{2}$

Continence in sex and industry in work were correlative and complimentary virtues. The Respectable Economic man must not be the sensual man who had failed to conquer himself, but the Respectable sublimated sensual man. To maintain the correlation between industry and continence it was necessary to encourage the diversion of vital energy from making love to "getting on". Matthew Arnold perceived a direct relationship between money-making and soul-saving symbolized by the suicide of a certain Mr. Smith, secretary to an insurance company, who "laboured under the apprehension that he would come to poverty, and that he was eternally lost." For Arnold a "middleclass" outlook pervaded the nation. "But how generally, with how many of us, are the main concerns of life limited to these two: the concern for making money, and the concern for saving our souls! And how entirely does the narrow and mechanical conception of our secular business proceed from a narrow and mechanical conception of our religious business!" 3 Grant Allen, the Late Victorian rebel,

1 Functions, (1862 ed.), pp. 50, 51. "Physiologists say, on a priori ground, that if you spend nervous force in one direction, you will not have as much to spend in another... An incessant action of the brain often seems to diminish the multiplying power... But the doctrine of abstract physiology must be applied with caution..." Walter Bagehot, Economic Studies, ed. R. H. Hutton (London, I905), pp. xi8-i 19.

2 Functions (1867 ed.), pp. 64, 55-69.

3 Culture and Anarchy, p. II6. 
known as the "St. Paul of Free Love", enlarged the correlation: making money, saving souls, and sublimating sexual energy. In Allen's words: ". . . love is a thing to be gotten over once and for all in early life, and relegated henceforth to the back parlour of existence in the most businesslike way, so that the mind be free for the serious affairs of alternating psalm-singing and retail trading. No romance must interfere with the solid worship of Mammon." 1

To such considerations, Acton was impervious, not understanding, but expounding the normative sexual standard and related problems absorbed his energies. Though as a doctor Acton had "daily cause to regret" that pecuniary considerations made early marriages impossible for many of his patients, he nevertheless believed that no doctor ought to prescribe early marriages to "the hardly-worked" Londoner. "It often interferes with work and success in life," he reasoned. "The sighing lackadaisical boy under [twenty-five] should be bidden to work, righteously and purely, and win his wife before he can hope to taste any happiness or benefits of married life." 3 For the same reason Acton opposed the long engagement, "an almost unmitigated evil." It was a state of affairs apt to cause sexual excitement. It was far wiser for the young man to devote himself to his profession exclusively, and not attempt to divide his attentions between his betrothed and "success in life." "When the latter is attained, it will be time to think of the former - and he will be in a position to select his partner for life." "Acton stood in the same relation to the gospel of continence as Samuel Smiles did to the gospel of work. Acton was the Smiles of continence.

Acutely aware of the extent of mid Victorian prostitution ${ }^{5}$ and disposed toward moral reform, Dr. Acton incessantly sermonized on the theme of complete continence. "To all young men," he wrote, "I advice strict continence." "While the Plutarchs of self-made heroes,

1 "The New Hedonism," Fortnightly Review, N.S., LV (1894), p. 390 . Both Arnold and Allen located the stronghold of the Respectable norm in the lower middle class. It is a commonplace assertion. "If English morality could be judged by the standard of morals which exists amongst the lower section of the middle class, the small shopkeeper and other employers on the same level, there would be no reason not to congratulate ourselves most heartily upon it. Between the lowest class and the professional class there is a happy interspace of virtue." H. Anstruther White, "Moral and Merrie England," Fortnightly Review, 1885, pp. 775-6. See also H. D. Traill, "The Abdication of Mrs. Grundy," National Review, 1891, pp. I 2-16.

2 Functions, (1857 ed.), p. 18.

3 Functions, (1862 ed.), p. 53.

4 Ibid., pp. 53-4.

5 Acton supported the extension of the Contagious Diseases Act. See his The Contagious Diseases Act, Shall the Contagious Diseases Act be Applied to the Civil Population? (London, 1870). See also his Prostitution.

${ }^{6}$ Functions, ( 1857 ed.), p. $8 \mathrm{r}$. 
like Samuel Smiles, and classical economists, like Henry Fawcett, declared that the individual must either be thrifty or extravagant, idle or industrious, Acton, the Smiles of continence, declared that there was "no middle course; a man must either be continent or incontinent." According to Acton's definition of continence, masturbation was excluded. "Continence must be entire." "Continence consists not only in abstaining form sexual congress, but in controlling all sexual excitement." 1 Acton always saw man either as Prodigal or Respectable. Once a habit, entire continence, not occasional incontinence and continence, had the great advantage of making virtue easier, the perfectly continent secreting sexual energy very slowly. ${ }^{2}$ Licentious reading, the ancient and modern French classics, and idleness induced a great secretion of sexual energy. ${ }^{3}$ To keep its secretion to a manageable quantity, Acton prescribed the following panacea: daily bathing, sleep on a hard bed with a light covering, a moderate diet (his most extreme advice being not to take food after 4 o'clock), abstinence from strong drink, intellectual diversion, the trained "aversion ... of the will from sexual subjects", the development of the sense that all indulgences are "dirty and mean", and yielding disgraceful, the aid of religious teaching, and vigorous physical exercise. ${ }^{4}$ Acton praised both the work of the Y.M.C.A. and the Volunteer movement for their influence in promoting continence. ${ }^{5}$

The gospel of continence and the Respectable theory of sublimation was of course not confined to physicians. It was, for instance, shared by the sponsors of the Respectable public school system. ${ }^{6}$ Dr. Acton, ever-vigilant, attested to the "manliness" and the "purity" of the large schools. He cautioned against the occasional manifestation of "platonic attachment", and took strong objection to the exposure of young men to the sensuality of the classical curriculum. Acton challenged the allegation that the classics on the one hand, the fully detailed and universally reported Divorce Court proceedings and "Police Intelligence" on the other hand, were equally immoral. Acton dissented. Their immorality did not parallel. No matter how sordid, the divorce case was always morally concluded in that vice was "actually being exposed and held up to public ignominy and execration." ?

1 Functions, (1862 ed.), pp. $27-8$.

2 Ibid.

3 Ibid., pp. 20-I.

4 Ibid., p. 45.

5 Ibid., pp. 40-9.

- See, e.g., George R. Parkin, Edward Thring, Headmaster of Uppingham School, Life, Diary and Letters (London and New York, r900), and L. V. Lester, A Memoir of Hugo Daniel Harper (London, N. Y., and Bombay, 1896).

7 Functions, (1862 ed.), Pp. 21. 
Whether boys are exposed to the classics or not, wherever they are gathered, vice was sure to be lurking. The great insurance for virtue in the public school was to establish a "public opinion" in its favor as Acton's model headmaster, Dr. Arnold, did. Masters should aim to make virtue, propriety, and self-restraint "fashionable". Boys ridiculed virtue. They could be made to ridicule vice. "It has frequently been done," wrote Acton, "and by the same means of frank sympathy, thorough earnestness, and spotless rectitude in the instructors, it can be done again. The help which such a tone of feeling would be to a wavering boy is incalculable. Supported by such a public opinion he need not blush when tempted or jeered by the licentious. Innocence, or even ignorance of vice, will no longer be a dishonor or a jest. The better disposed will reprove any immorality immediately, and utterly discountenance all conduct inconsistent with the character of a Christian and a gentleman. No one can have read the life of the late Dr. Arnold without seeing that it was one of the chief objects of his life to establish some such feeling as this among his boys. That he was to a great extent successful those who have had the fortune to become acquainted with any number of his pupils will be the first to acknowledge." Acton had even more reason to be hopeful. A rector who had associations with three public schools wrote Acton that in them "all open or avowed practice of the vice of masturbation was sternly repressed by the force of public opinion." 1 "We talk of sending our boys to such and such a public school, because the tone there is so good. What do we mean? We mean that the traditions of the school set rather towards virtue than towards vice." 2 So wrote the Rev. John Mitchinson in a vein that suggests virtue was being universalized throughout the Respectable public school system.

The great moral changes wrought in the public school system in the generation preceeding 1860 was commented upon by the "Literary Gazette".

"But in nothing has there been manifested a more striking improvement than in the revolution given in our great schools. We should feel it impossible to believe that now, as thirty years ago, the head-master of one of our largest public schools could say, when the subject of some immorality was brought to his notice as prevalent in his school, that his business was to teach the boys Greek, not morals. Now thanks mainly to Dr. Arnold, and the ernest band of men who have sprung up, either under his

1 Functions, (1867 ed.), pp. 35-6, 40.

2 Rev. John Mitchinson, The Christian Gentleman's Training (Oxford and London, I878) p. I 2. 
immediate care, or as admirers of his devotion to the cause of education in its noblest and widest sense, our foundation schoolmasters whether in wider or more limited spheres, are impressed with the responsibilities and opportunities of their position as the great influences of the young ... a and every effort is made to cast the plastic mind of the young in the mould of Christian purity." 1

The moral improvement in the public schools was not only attested to by the Public Schools Commissioners in 1864 , but they also ascribed to the schools "the improved moral tone of the Universities" for which they had "strong concurrent testimony." 2

The theory of sublimation adopted in the mid-Victorian public schools emphasized the diversion of energy into several outlets including the intellectual. In Dr. Arnold's enumerated purposes of education the cultivation of the intellect ran a poor third after the teaching of religious and moral principles and of gentlemanly conduct. ${ }^{3}$ The cultivation of the intellect fared even worse in the succeeding two generations. A. C. Benson, an Etonian master, wrote that "intellectual things are, to put it frankly, unfashionable." 4 On the contrary the Respectable schools emphasized the expenditure of energy primarily through its concentration upon organized and compulsory sports and games. It was only in late-Victorian England that Eton's best athletes, hitherto in the school's history honored by the boys themselves, received official recognition as the school's leading boys. ${ }^{5}$ In the public school the absorbing routine of work and sports consumed all the boy's time in a whirl of unreflecting activity, leaving no time for thought and observation. The boys found it difficult to be alone, or to discover their own minds, or their individual selves, or their own aspirations. "There is no disturbing or inspiring sense of something wanting," wrote S. H. Jeyes, "no feeling about for a self that has gotten itself lost in the hum and bustle of a corporate existence. The aim is rather to conform to the recognized standard, to live up the highest mark of the established etbos, to win as many prizes in examin-

1 "F. C.", "Education," Literary Gazette, I 3 Oct., 1860, p. 308.

2 Report of Her Majesty's Commissioners . . . (I 864), I. p. 44.

3 E. C. Mack, Public Schools and British Opinion, 1780 to 1860 (London, 1938), pp. 249-50.

4 "... we send out from our public schools year after year boys who hate knowledge and think books dreary, who are perfectly self-satisfied and entirely ignorant, and, what is worse, not ignorant in a wholesome and humble manner, but arrogantly and contemptuously ignorant - not only satisfied to be so, but thinking it ridiculous and almost unmanly that a young man should be anything else." A. C. Benson, The Schoolmaster: A Commentary Upon the Aims and Methods of an Assistant-Master in a Public School (London, 1902).

5 Christopher Hollis, Eton, a History (London, 1960), p. 294. 
ations and as many caps and ribbons in the playing-field $s$ as possible, to excel one's companions, if one can, but only on their lines..."1 The system or corporate work and play did not grow up fortuitously. In Jeyes' words "It is pursued of set purpose - it keeps the boys out of mischief. It acts as a sort of auto-moral sanction of morality. Nor can its efficiency or the importance of its results be called into question." 2

The ideal of this "Muscular Christianity" was personified in a passionless manly reserve. The periodical, "London Society", recognized the identity of the public school prototype and "good society's" expectations of manliness. "Good Society hates scenes, votes every eccentricity of manner and demonstrativeness of demeanour bad form; the schools have followed suit, and the ideal of deportment which an Eton and Harrow boy proposes to himself is of pure passionless exterior... The Etonian has schooled himself into undemonstrativeness persistently and well." 3

The qualities of coldness and of manly reserve were found in the reality of the family itself. Mill's experience was not unique. "In English family life there is no intimacy, no openness of heart; stiffness and reserve; affection, but little love." Max O'Rell marked the contrast with France. "A son never kisses his father," and only rarely his mother. He shakes hands, the effusion of the heart goes no further. An English son would be afraid of losing his dignity if he caressed his mother. In France, our mother is the recipient of our tenderest caresses, our nearest and dearest friend." 5

The Respectable Gentlemanly ideal of a "passionless exterior", of "undemonstrativeness" of demeanor, of manly reserve, and of coldness found poetical expression in Tennyson's Arthur, a popular gentle-

1 S. H. Jeyes, “Our Gentlemanly Failures.” Fortnightly Review, N.S., LXI (1897), p. 392.

2 Ibid, p. 391.

3 "Public School Types," London Society, XVI (1869), p. 34.

4 "On my twelfth birthday I went up as usual to kiss my father. He said gravely, 'Shake hands; you are growing too old for kissing.' I felt rather ashamed of having offered what my twelfth birthday rendered unseemly, and took a step upon the path towards isolation... Henceforth I shrank from the exposure of emotion except upon paper, in letters and in studied language." Horatio F. Brown, John Addington Symonds. A Biography Compiled From His Papers and Correspondence (London, r 895), I, p. 64. "Curious, the covered underground life that some children lead! I never remember, all those years at Brighton, till I was nineteen or twenty, a single person older than myself who was my confident. I do not remember a single occasion on which in any trouble or perplexity I was able to go to any one for help or consolation. My mother, firm, just, and courageous as she was, and setting her children an heroic example, belonged to the old school, which thought any manifestation of feeling unbecoming. We early learned to suppress and control emotion, and to fight our own battles alone: in some ways a good training, but liable in the long run to starve the emotional nature." Edward Carpenter, My Days and Dreams, Being Autobiographical Notes (London, I916), pp. I , 28-30, 94-98.

b Max O'Rell, John Bull and his Island (London, [1883?]), pp. 3 1-32. 
manly image of the ideal husband. Guinevere found Arthur cold, neglectful, and irresponsive. Unconscious of any personal faults, Arthur was oblivious of any guilt in Guinevere's adultery. When it was exposed, he first contemplated the question of burning her. Having dismissed this notion, he addressed to Guinevere a "farewell sermon of Pharisaic forgiveness", a sermon of "unctious selfrighteousness". ${ }^{1}$ There was indeed a receptive public for such sentiments. With the publication of the first four "Idylls of the King" in I 859 Tennyson was said to have won the governing classes. ${ }^{2}$ In 1862 James Knowles, the journalist, remarked upon "the growing popularity of the Arthur story" as "a wholesome sign of the times." Knowles interpreted Tennyson's Arthur as standing "evidently for the Soul, the moral conscience, as the Round Table does for the passions; and everywhere the struggle of the Spirit with the Flesh is pointed." 3 The dichotomy between flesh and spirit pervaded all the "Idylls". Arthur symbolized the Sensual Man who had successfully and permanently conquered the flesh and lost the consciousness of sin. He is the Respectable Sensual Man par excellence. "Arthur is intended," says Tennyson's Late-Victorian and sympathetic critic, Henry Van Dyke, "to be a man in whom the spirit has already conquered and reigns supreme. His task is to bring his realm into harmony with himself, to build up a spiritual and social order upon which his own character, as the best and highest, shall be impressed. The foes that oppose him to the end are the evil passions in the hearts of men and women about him." " $\mathrm{Or}$ in the trenchant words of a rebel against Respectability:

"The Tennysonian Arthur ... is the ideal of the modern gentleman", and it was necessary to make his character as faultless and immaculate - in a word, as gentlemanly as possible. The offensive elements of the legend - offensive to the pious family taste of the nineteenth century - having been carefully eliminated, 5 we are introduced to a perfect Arthur, a Prince Consort idealised, who has cultivated the domestic virtues till he is a positive paragon of

1 H. S. Salt, Tennyson as a Thinker, a Criticism (London, 1891), pp. 40-41.

2 G. M. Young, To-Day and Yesterday (London, I 948), p. 43.

3 Cited in Alan Willard Brown, The Methaphysical Society, Victorian Minds in Crisis (New York, 1947), p. 14. For a current interpretation of the Idylls differing from the meaning given to them by the Victorian critics cited in this essay, see F. E. L. Priestly, "Idylls of the King - A Fresh View", ed. John Killham, Critical Essays on the Poetry of Tennyson (London, 1960), pp. 239-55.

4 Henry van Dyke, The Poetry of Tennyson (roth ed., New York, 1904), p. I98.

b The reference is to the change in the Arthur legend from Mallory's use of the incestmotif to Tennyson's use of the adultery-motif. 
bourgeois respectability; there is no flaw in him, except, indeed, that he proves in the sequel (though this was quite unintended by the poet, and is not recognized by him) to be an insufferable nincompoop and prig." 1

While the Public School System, "Good Society", and in general the overwhelming publicly articulated opinion perennially exhorted young gentlemen to be pure and thereby buttressed the Respectable norm, there was one significant area of resistance to the Respectable norm. While thirty ${ }^{2}$ became the average age when gentlemen married between 1840 and 1870 , the "wide-spread belief" prevailed that a young man could not live a continent life to the age of twenty-five without injury to his health..$^{3}$ The belief was an important factor in the exoneration of masculine indulgence. 4 Patients, particularly "exceptional men of abnormal passion", expected physicians to prescribe fornication..$^{5}$ They believed that disuse of their sexual organs caused them to atrophy and rendered them impotent. ${ }^{6}$

The medical profession itself was divided on the question of the gentleman's abstention or indulgence in premarital sexual intercourse. Two distinct classes of medical opinions prevailed among physicians. One class advocated sexual indulgence; a doctrine allegedly of French origins and associated with the fact that medical students often finished their education in Paris. ${ }^{7}$ The best known of their books was George R. Drysdale's anonymously published "The Elements of Social Science". 8 It was alleged, by one of the book's critics who declined to identify it and thereby advertise it, to express "boldly the carefully whispered opinions of many medical men, who, immoral themselves, advise their patients, male and even female, to practice

\section{H. S. Salt, op. cit. pp. 37-38.}

2 J. A. Banks, Prosperity and Parenthood, p. 48.

3 Dr. Elizabeth Blackwell, Counsel to Parents on the Moral Education of their Children in Relation to Sex (London, 1879), pp. 62-3. See also William Logan, The Great Social Evil. Its Cause, Extent, Results, and Remedies (London, I 87I), p. 228. "The upholders of the law [the Contagious Diseases Acts] were obliged openly to declare as their belief, and as the basis of this legislation, the doctrine of the necessity of vice for men, and of the impossibility of self-restraint; and then was called forth the public denial of that doctrine."

J. E. Butler, op. cit., pp. 30-I.

4 F. W. Newman, "Remedies for the Great Social Evil," Miscellanies (London, 1889), III, pp. 274-5.

5 "Many of your patients will ask about sexual intercourse, and some will expect you to prescribe fornication." R. Paget, Clinical Lectures, p. 293.

6 Acton (1857 ed.), p. 19 and (1862 ed.) pp. 29-3o.

7 F. W. Newman, "On State Provision for Vice," Miscellanies, III, p. 244; W. Logan, op. cit., pp. 229-30.

8 The Elements of Social Science, See p. 22, n. 2. 
immorality." 1 Drysdale contended that sexual union from the age of puberty was "the natural requirement and right of every person, male and female, and that nothing ought to prevent its free and frequent exercise." To this end Drysdale advocated the use of contraceptives. "Instead of being i mmoral," Drysdale believed, "preventive intercourse is the only' possible way of introducing real morality into buman society". 2 Drysdale asserted that the generative organs, like all other organs, were subject to the law of exercise: "It is a duty and necessity to give them this exercise from the age of puberty, till their decline." It was alleged that the thesis had been "adopted by not a few of the more ignorant or unprincipled members of the profession". ${ }^{3}$

A second class of medical opinion, more vocal than the first, advocated sexual continence to the age of twenty-five, to be followed by early marriages. ${ }^{4}$ This body of opinion emphasized the compatability of continence and physical health. ${ }^{5}$ It decried the sexual atrophy and disuse argument as "utterly unscientific". ${ }^{6}$ Sir James Paget told medical students never to advise that which was "morally wrong" even if there were reason to believe that a patient's health would profit from the "wrong-doing".7 In general, this class of opinion believed, Acton excepted, in a single standard of morality. (Acton supported the contagious Diseases Acts which legalized the double standard.) Nichols epitomized the position of this class of medical opinion: "There can be no right of men to destroy a certain number of women, making them the victims of their lusts, in order that those they marry may be virtuous." 8

1 T. L. Nichols, Physiology, pp. 301, 64,300.

2 Elements, p. 352.

3 T. L. Nichols, op. cit., pp. 300-I. Acton, too, attacked an "unidentified writer of no mean standing or ability" whom Acton quoted as follows: "The ignorance of the necessity of sexual intercourse to the health and virtue of both men and women, is the most fundamental error in medical and moral philosophy." "It may be mentioned as curious, that a young man entering on puberty is to indulge the exercise of all his organs, all his feelings, except that of the most violent - namely, love." The unidentified writer who was in fact Drysdale advocated a social sanction for "unmarried intimacy", "precaution being taken to prevent the famales having children." Acton, op. cit. (1862 ed.), pp. 29-30.

4 E. Blackwell, op. cit., pp. 74, 75, 81, 95, 103. "With early marriages what a sweepingaway will there be of immorality, often justified now by an appeal to natural laws, on the one side, and of grievous disturbance of the nervous system, due to injured vitality, on the other." The latter assertion, the writer said, was borne out by "pathological study". Mrs. B. A. Crackenthorpe, "The Revolt of the Daughters," Nineteenth Century, March, I 894 , p. 428 .

5 "A Graduate", op. cit. pp. I I-1 2.

- T. L. Nichols, Physiology, pp. 300, 372, and Anthropology, p. I 14.

7 Sir James Paget, Lectures, pp. 293-4.

8 T. L. Nichols, Anthropology, p. 17. 
"In the cause of public purity and modesty" this class of medical opinion, joined by the social purity reformer, F. W. Newman, advocated fundamental reforms in the treatment of female maladies by male surgeons and physicians. T. L. Nichols wrote of the "needless and shameless examinations, with fingers and speculum", and of "libidinous manipulations", to which women and even young girls were subjected; being "everywhere outraged and abused". ${ }^{1} \mathrm{~F}$. W. Newman spoke of the general belief that young medical students were more licentious than other young men. He lamented the "fact" that physicians took advantage of fallen women and liberties with married women. Newman contended that medical duties of the young surgeon were more likely to inflame his passions than to frighten him. His chastity was made infirm and his delicacy blunted. "It is difficult to imagine how any medical man can retain delicacy, who has to go through the ordeal of introspecting a long string of women in the shortest possible time." Newman proposed the following panacea: "Let the study of female disease and female anatomy be withheld from young men in the public hospitals and medical schools, at least as soon as women have been made competent." F. W. Newman for all his distaste of Catholicism proposed that "Priestesses" instruct young girls on sexual morality. The efficacy of the confessional in Catholic countries in preserving female chastity inspired his recommendation. ${ }^{2}$

While the belief in the necessity for indulgence constituted an important area of resistance to the Respectable norm and divided the medical profession, and while purity reformers and advocates of indulgence coexisted in and out of the medical profession in the fifties and sixties, the advocates of "purity" from the seventies onward grew in strength and militancy. The relatively laissez-faire attitude of the fifties and sixties in respect to London's flourishing night life contrasted remarkably with its termination early in the seventies when several famous salons, night houses, casinos, and pleasure gardens were closed down. ${ }^{3}$ Certainly a shift in the relative position of the Respectable norm and the double standard was discernible in the new unwillingness to tolerate the open moral laxity of the fifties and sixties as it was manifested in public entertainment.

The shift from the sixties to the seventies was to be observed in the repeal of the Contagious Diseases Acts. The relatively strong position of "impurity" in the sixties was evidenced in the legal sanction given

1 Ibid., pp. 98-99.

2 F. W. Newman, Miscellanies, III, pp. 279, 280, 273.

3 Cyril Pearl, The Girl with the Swansdown Seat (London, 1955), ch. v. 
to the double standard of morality through the passage of the Contagious Diseases Acts of 1864, I866, and I869. These Acts provided for the state regulation of prostitution in certain ports and military stations. Accepting the belief that a double standard was inevitable, the Acts assumed the need for prostitution and a farther need to control and regulate the conduct and health of prostitutes in order to safeguard the public, especially soldiers, from venereal diseases. Alleged prostitutes and known prostitutes were consequently subjected to special regulations which required them to submit to police registration and to regular medical examination for the detection of venereal diseases. If diseased, they were compulsorily detained in certified hospitals until discharged by the visiting surgeon. The Laws showed no direct concern for the number of women which diseased men infected. Thus the Acts, accepting double moral standard, sought to safeguard public health through a form of discrimination against women from which men escaped both blame and responsibility.

As in the case of public entertainment, so in the legal standing of the double standard was a shift discernible in the relative strength of the Respectable norm and the double standard. From 1869 onward the courageous Josephine Butler led the campaign against the Contagious Diseases Acts. For her the double standard was an integral part of the larger whole, the subjection of women. She, therefore, "concentrated on the most extreme and brutal example of the subjection of women the State Regulation of Prostitution." 1 She conceived the campaign for repeal of the Acts in reference to the larger movement for the emancipation of women. Their emancipation required not only the same standard of morality, but the right to vote, and equal access to education and employment. ${ }^{2}$ The Acts were suspended in 1883 and finally repealed in 1886 . Their repeal represented the state's withdrawal of its sanction of the double standard. Belief in the necessity of a double standard persisted, but a relatively new issue emerged to complicate the controversy: the issue of what the single standard of morality was to be for both men and women.

For the sin of sexual indulgence, a gentleman, it was said in 1863 , "was left to be dealt with by individuals according to their estimate of the particular circumstances of the case." 3 After the campaign, extending over two decades, for social purity, or a single standard of sexual morality, when Sexual Respectability permeated "the entire

1 Notes for Speakers on the Work and Principles of Josephine Butler (Westminster, I928), p. I 2.

2 Ibid., p. s. See also J. E. Butler, op. cit., v. Crawford, op. cit., and J. Butler, The Education and Employment of Women (London, I868).

3 "Anti-Respectability," Cornhill Magazine, VIII (1863), p. 289. 
'formation' of society, with the exception of its very lowest deposits of ignorance and barbarism, and its 'top dressing' of aristocratic idleness and profligacy", ${ }^{1}$ and after the prolonged campaign to enlarge the freedom of women, ${ }^{2}$ the differential treatment accorded to ladies and gentlemen was considerably narrowed. "It is, of course, the woman who, as a general rule, has to pay the heavier penalty; but it is not true, as sometimes represented, that society inflicts its vengeance upon her alone. This social code claims its hecatombs among men also." 3

In particular, politicians had been compelled to submit to the code of Sexual Respectability. The unwritten electoral law required politicians to be "pure" in their private lives. The downfall of Sir Charles Dilke and Charles Parnell beared this out. "A politician," bewailed H. D. Traill, "may be a liar, a procurer of murder and outrage, an organizer of conspiracies to defraud... so long as he is "pure'." ${ }^{4}$ The decalogue had been reduced to the sixth commandment. According to a profile written by W. T. Stead, "the professional righteous man", "righteousness caricatured", 5 Dilke had gone wrong, as all well-to-do young men went wrong if they had been raised without a mother and without religion. "That is a general law to which there are few exceptions." ${ }^{6}$ According to Traill, the political personification of "purity" was Gladstone: "the interweaving of morality with national politics has been a task congenial to the nature of Mr. Gladstone." 7

(To be concluded in the next issue).

1 "Continence even to the point of asceticism, has become as universally recognized an obligation of human life as the restraint of other appetites once freely and almost without reproach indulged in even by persons of position and refinement." H. D. Traill, op. cit., pp. I I, I5-16.

2 There had "arisen two quite diverse movements; the one to restrain the sexual freedom of men; the other - of course, less outspoken and manifest, but very active in many quarters - to give greater sexual freedom to women." Karl Pearson, "Woman and Labour," Fortnightly Review, I May, 1895, p. 568.

3 Beswicke Ancrum, "The Sexual Problem," National Review, I891, pp. I2-I3.

4 H. D. Traill, op. cit., pp. r2-13.

5 "Public Life and Private Morals," Fortnightly Review IXL (1891), p. 217.

- Review of Reviews, August 1892, pp. 127-141, 130.

7 H. D. Traill, op. cit. p. I3. 